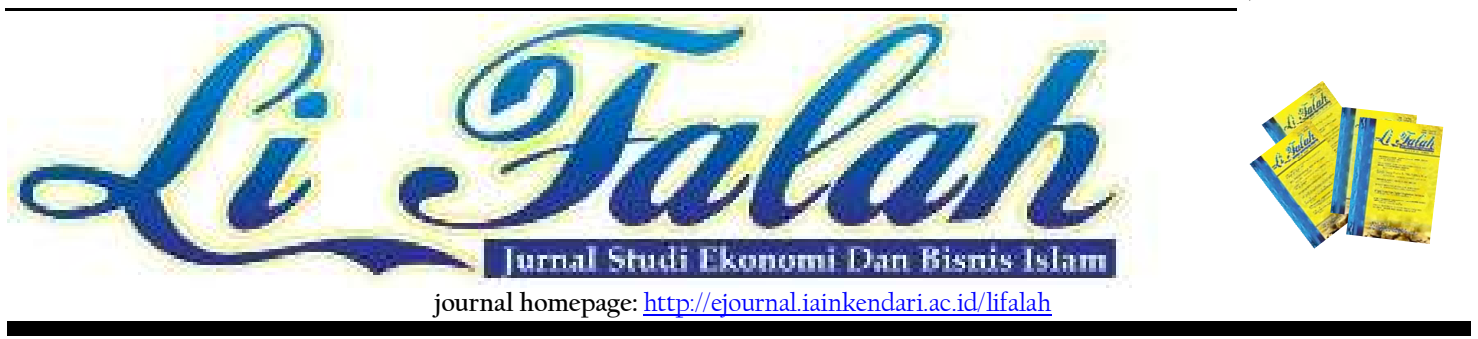

\title{
Studi Komparasi Pemikiran John Maynard Keynes Dan Yusuf Qardhawi Tentang Produksi
}

\section{Syamsudin Mochtar}

Institut Agama Islam Negeri (IAIN) Kendari

Email:syams6604@gmail.com

\section{INFO ARTIKEL}

Keywords: John Maynard Kenes, Yusuf Qardhawi, Produksi

DOI:

http://dx.doi.org/10.31332/lifalah.v4i2.1522
A B S T R A K
Penelitian ini bertujuan untuk mengetahui dan menganalisis konsep produksi konvensional dalam pandangan John Maynard Keynes dan konsep produksi Islam dalam pandangan Yusuf Qardhawi. Jenis penelitian ini adalah kualitatif dengan pendekatan library research yaitu lebih menitik beratkan pada pengumpulan data dari berbagai sumber yang relevan dengan metode dokumentasi.

Kegiatan produksi merupakan respon terhadap kegiatan konsumsi, untuk memenuhi kebutuhan masyarakat dan memperoleh keuntungan maksimum. Proses produksi dalam literatur konvensional, hanya ditujukan untuk memaksimalkan keuntungannya maupun mengoptimalkan efisiensi produksinya, maka dalam ekonomi Islam tidak hanya demikian, akan tetapi adanya penekanan untuk memperhatikan kemungkinan munculnya dampak sosialspiritual menjadi ciri khas yang cukup untuk membedakan keduanya.

Penelitian ini menyimpulkan bahwa John Maynard Keynes menyatakan proses produksi ditujukan untuk memaksimalkan laba tanpa memikirkan dampak spiritualnya, sedangkan Yusuf Qardhawi lebih menitik beratkan proses produksi pada nilai dan akhlaknya. 


\section{Pendahuluan}

Membahas proses kegiatan ekonomi, aktivitas produksi merupakan elemen penting yang sangat menentukan bagi pemenuhan kebutuhan hidup manusia. Bahkan tak menutup kemudian ia menjadi kendali dalam semua level kegiatan ekonomi. Sebab tanpa diawali proses produksi, kegiatan konsumsi, distribusi ataupun perdagangan barang dan jasa tidak akan pernah ada. Secara umum, produksi merupakan proses untuk menghasilkan suatu barang dan jasa atau proses peningkatan utility (nilai) suatu benda. Dalam istilah ekonomi, produksi merupakan suatu rentetan kegiatankegiatan ekonomi untuk menghasilkan barang atau jasa tertentu dengan memanfaatkan faktor-faktor produksi dalam jangka waktu tertentu.

Setiap produsen maupun perusahaan akan berusaha untuk mencapai hasil yang lebih tinggi dalam menyelenggarakan suatu usaha. Produsen akan memutuskan untuk meningkatkan faktor produksi jika diyakini bahwa tambahan faktor produksi tersebut akan memberikan tambahan hasil yang lebih besar. Analisis prilaku produsen tersebut sehubungan dengan jenis dan penggunaan faktor produksi dalam teori produksi, yaitu hubungan antara input dan output.

Seiring dengan laju pergerakan zaman yang terus berjalan, banyak dari para pelaku ekonomi tidak saja bertujuan untuk memenuhi kebutuhan hidupnya, namun mereka juga telah berani mengabaikan nilai etika-religius dalam menjalankan kegiatan ekonominya. Dalam aktivitas produksi misalnya, disana yang terjadi tidak hanya upaya untuk mengadakan penyediaan barang-barang konsumsi, akan tetapi terkadang kecenderungan mengeruk keuntungan (profit) sebanyak-banyaknya telah menafikan nilai kemanusiaan serta mengabaikan dampak sosial (social impact) yang harus dialami oleh pihakpihak tertentu.

Secara garis besar, sistem ekonomi dapat dikelompokkan, yaitu konvensional dan Islam. Perbedaan mendasar antara sistem ekonomi konvensional dan ekonomi Islam dapat dilihat dari prinsip pembiayaannya. Sudah menjadi common sense sistem ekonomi konvensional mengaplikasikan sistem bunga pada hampir seluruh pembiayaan

dalam berbagai kegiatan ekonomi. Sebaliknya, ekonomi Islam sangat

Perbedaan sistem ekonomi Islam dengan sistem ekonomi konvensional secara umum dapat dilihat dari beberapa sudut berikut; (1) Sumber (Epistemology): Sebagai sebuah ad-Din yang sumbernya berasaskan kepada sumber yang mutlak yaitu Al- Qur'an dan Al-Sunnah. Kedudukan sumber yang mutlak ini menjadikan Islam itu sebagai suatu agama ad-Din yang istimewa dibanding dengan agama-agama ciptaan lain. Sedang ekonomi konvensional tidak bersumber atau berlandaskan wahyu. Oleh karena itu, ia lahir dari pemikiran manusia yang bisa berubah berdasarkan waktu atau masa sehingga diperlukan maklumat yang baru. (2) Tujuan Kehidupan: Tujuan ekonomi Islam membawa kepada konsep al-falah (kejayaan) di dunia dan akhirat, kebahagiaan bagi pelaku ekonomi baik di dunia maupun di akhirat, sedangkan ekonomi sekuler untuk kepuasan di dunia 
saja. Ekonomi Islam meletakkan manusia sebagai khalifah di muka bumi ini. (3) Konsep harta: Islam menjelaskan bahwa harta bukanlah merupakan tujuan hidup tetapi sekadar wasilah atau perantara bagi mewujudkan perintah Allah SWT. Tujuan hidup yang sebenarnya ialah seperti firman Allah SWT QS. Al An'am/6: 162:

Terjemahnya.

"Katakanlah: sesungguhnya sembahyangku, ibadatku, hidupku dan matiku hanyalah untuk Allah, Tuhan semesta alam".

Harta bukanlah tujuan utama kehidupan tetapi adalah sebagai jalan untuk mencapai nikmat ketenangan kehidupan di dunia hingga ke alam akhirat. Ini berbeda dengan ekonomi konvensional yang meletakkan keduniaan sebagai tujuan yang tidak mempunyai kaitan dengan Tuhan dan akhirat sama sekali.

Secara garis besar, tujuan yang ditawarkan oleh John Maynard Keynes dan Yusuf Qardhawi dalam produksi, yaitu untuk meningkatkan produktifitas, itu memang senada. Namun di sela sela pemaparan keduannya tentang produksi, terdapat perbedaan dalam menyikapi proses dan hasil produksinya.

Berangkat dari fakta tersebut di atas, akan menjadi satu kajian yang menarik bila kemudian kita mencoba untuk menelaah lebih dalam lagi tentang sistem produksi dalam ekonomi konvensional dan islam menurut pandangan John Maynard Keynes dan Yusuf Qardhawi. Diharapkan dalam penelitian ini akan lahir pemahaman bahwa yang menjadi orientasi utama dalam sistem produksi Islam bukanlah sekedar mengeruk keuntungan (profit) belaka, akan tetapi adanya pemeliharaan terhadap nilai etikareligius yang justru menjadi bagian terpenting yang tak boleh diabaikan.

\section{Biografi John Maynard Keynes}

John Maynard Keynes (selanjutnya disebut Keynes), lahir pada tanggal 5 Juni 1883 dan meninggal pada 21 April 1946, ia adalah ekonom Inggris yang gagasannya mengubah teori dan praktik ekonomi makro serta kebijakan ekonomi dunia. Ia melanjutkan dan memperbaiki teori sebelumnya yang menjelaskan penyebab terjadinya siklus bisnis. Ia diakui sebagai salah satu ekonom paling berpengaruh abad ke-20 dan pendiri ekonomi makro modern. Pemikiranpemikirannya menjadi dasar mazhab ekonomi Keynesian dan semua turunannya.

Keynes menempuh pendidikan di sekolah terbaik di inggris eton and king's college. Di Cambridge ia belajar sastra klasik, dan filsafat kepada G.E Moore, Ilmu Matematika kepada Alfred North Whitehead dan Ilmu Ekonomi kepada Alfred Marshall. Keynes juga menjadi anggota kelompok eksekutif intelektual Cambridge, yang kemudian menjadi kelompok Bloomsbury. Setelah lulus Keynes mengikuti ujian British Civil Service dan mendapatkan skor tertinggi kedua dalam semua ujian. Hal ini membuat Keynes mendapatkan pilihan kedua posisi pelayanan sipil yang tersedia.

Setelah menempati jabatan di India, Keynes membantu mengorganisasikan dan mengkoordinasikan kepentingan inggris yang melibatkan India. Dua tahun kemudian, pada tahun 1908, ia kembali ke Cambridge untuk mengajar ekonomi. Tiga tahun setelah itu ia menjabat sebagai redaktur Economic Journal, yang pada 
waktu itu merupakan jurnal yang paling prestisius diseluruh dunia.

Tahun 1940 Keynes menjadi penasehat ekonomi pemerintah inggris, kemudian tahun 1941 menjadi gubernur bank inggris dan tahun 1942 ia mendapatkan gelar kehormatan dari kerajaan inggris dan memperoleh nama Baron Keynes dari Tilton.

Hal ini membuat Keynes menjadi terkenal sebagai salah satu tokoh ekonomi dunia. Sampai saat ini, teori-teori sampai buku-bukunya masih dipakai sebagai referensi oleh seluruh masyarakat dunia yang ingin mengetahui perkembangan ekonomi dari mulai zaman dahulu sampai sekarang karena hal ini sangat penting bagi kita yang ingin mengetahui bagaimana sejarah dan perkembangan ekonomi.

\section{Biografi Yusuf Qardhawi}

Yusuf Qardhawi lahir pada tanggal 9 September 1926 di desa Shaft Turab Mesir bagian barat dengan nama lengkap Muhammad Yusuf Qardhawi (selanjutnya disebut Qardhawi). Ia berasal dari keluarga yang taat menjalankan ajaran agama Islam.

Ayahnya meninggal dunia ketika Ia masih berusia dua tahun, kemudian diasuh oleh pamannya yang keluarganya pun taat menjalankan ajaran Islam, Sehingga ia dididik dan dibekali dengan ilmi-ilmu pengetahuan agama dan syariat Islam. Maka tidak heran jika Qardhawi tumbuh menjadi seorang yang taat beragama.

Ketika usianya lima tahun Qardhawi sudah dididik menghafalkan Al-Quran secara intensif oleh pamannya dan sudah hafal Al-Quran dengan fasih ketika usianya sepuluh tahun. Pada usianya yang ke tujuh Ia mengenyam pendidikan umumnya di Sekolah Dasar Al-Ilzamiyah yang berada di bawah Departemen Pendidikan Mesir. Di sekolah ini Ia mempelajari berbagai ilmu pengetahuan umum, seperti matematika, ilmu kesehatan dan ilmu sejarah. Kemudian Ia melanjutkan pendidikannya di Sekolah Menengah Pertama dan Sekolah Menengah Umum di Thanta dalam waktu yang relatif singkat dan prestasi terbaik.

Tahun 1953 Ia berhasil menyelesaikan kuliahnya di Fakultas Ushuludin Al-Azhar dengan peringkat terbaik, kemudian Ia melanjutkan pendidikan kejurusan Bahasa Arab di Ma'had al-Buhus Ad-Dirasat Al-Arabiyah Al-Aliyah sehingga mendapatkan diploma tinggi di bidang bahasa dan sastra selama dua tahun. Pada tahun 1957, Qardhawi melanjutkan studinya di lembaga riset dan penelitian masalahmasalah Islam dan perkembangannya, selama tiga tahun. Kemudian Ia mendaftar pada tingkat pasca sarjana di Universitas Al-Azhar Kairo Mesir pada Fakultas Ushuluddin jurusan Tafsir Hadis dan berhasil di selesaikan pada tahun 1960 . Pada tahun 1972, Qardhawi mendapat gelar dari program doktornya yang ditempuh selama dua tahun, dengan disertasi "Zakat Dan Dampaknya Dalam Penanggulangan Kemiskinan", kemudian disempurnakan dalam bukunya berjudul Fiqih Zakat.

Qardhawi adalah ketua Jurusan Studi Islam pada Fakultas Syari'ah Universitas Qatar. Sebelumnya Ia adalah direktur Lembaga Agama Tingkat sekolah Lanjutan Atas di Qatar. Dalam bidang dakwah, Ia aktif menyampaikan pesan-pesan keagamaan melalui program 
khusus di radio dan televisi Qatar, antara lain melalui acara mingguan yang diisi dengan tanya jawab tentang keagamaan. Melalui bantuan Universitas, Lembaga lembaga keagamaan, dan yayasan Islam di dunia Arab, Qardhawi sanggup melakukan kunjungan ke berbagai negara-negara Islam maupun non-Islam untuk mengisi keagamaan.

\section{Pengertian Produksi}

Kata "produksi" telah menjadi kata Indonesia, setelah diserap di dalam pemikiran ekonomi bersamaan dengan kata "distribusi". Dalam kamus Inggris Indonesia kata "production" secara linguistik mengandung arti penghasilan.

Produksi adalah menciptakan, menghasilkan, dan membuat. Kegiatan produksi tidak akan dapat dilakukan kalau tidak ada bahan yang memungkinkan dilakukannya proses produksi itu sendiri. Untuk bisa melakukan produksi, orang memerlukan tenaga manusia, sumbersumber alam, modal dalam segala bentuknya, serta kecakapan. Semua unsur itu disebut faktor-faktor produksi (factors of production). Jadi, semua unsur yang menopang usaha penciptaan nilai atau usaha memperbesar nilai barang disebut sebagai faktor-faktor produksi.

Produksi menciptakan manfaat pada suatu barang dimana manusia hanya mampu menciptakan, sehingga praktek dalam kegiatan produksi memiliki empat faktor yaitu:

(1) Sumber daya alam (tanah): Islam telah mengakui tanah sebagai faktor produksi tetapi tidak setepat dalam arti sama yang digunakan di zaman modern. Dalam tulisan klasik, tanah yang dianggap sebagai faktor produksi penting mencakup semua sumber daya alam yang digunakan dalam proses produksi. Islam menjadikan alam sebagai salah satu faktor produksi, pemilik tanah dibolehkan memanfaatkan lahan agar hasil produksinya bertambah, dengan syarat hak miliknya merupakan tugas sosial dari Allah atas milik-Nya.

(2) Sumber daya manusia (Tenaga kerja): Tenaga kerja adalah faktor penting dalam produksi. Karena dengan tenaga kerjanya manusia dapat merubah apa yang terdapat pada alam dari suatu kemampuan produksi menjadi hasil-hasil pertanian serta menambah produksi barang-barang dan jasa-jasa dalam industri yang merupakan sumber kekayaan bangsa." Secara umum para ahli ekonomi sependapat bahwa tenaga kerjalah pangkal produktivitas dari semua faktor-faktor produksi yang lain. Alam maupun tanah takkan bisa menghasilkan apa-apa tanpa tenaga kerja.

(3) Modal: Modal merupakan hal yang sangat penting dalam suatu produksi. Tanpa adanya modal, produsen tidak akan bisa menghasilkan suatu barang atau jasa. Dalam Islam modal harus bebas dari riba. Dalam beberapa cara perolehan modal, Islam mengatur sistem yang lebih baik, dengan cara kerja sama mudharabah atau musyarakah. Hal ini untuk menjaga hak produsen dan juga hak pemilik modal, agar tercapai suatu kebaikan dalam suatu aktivitas produksi. Organisasi: Organisasi adalah upaya sejak mulai timbulnya ide usaha dan barang apa yang ingin diproduksi dan bagaimana kualitasnya dalam presepsi manager, kemudian ide tersebut dipikirkan dan dicarikan solusi dalam keperluan faktor-faktor produksi sebelumnya. Kelihatan tidak ada ciri-ciri istimewa yang dapat dianggap sebagai 
organisasi dalam suatu kerangka Islam. Tapi ciri-ciri khusus berikutnya dapat diperhatikan, untuk memahami peranan organisasi dalam ekonomi Islam.

Menurut Keynes terdapat tiga faktor produksi yang saling berhubungan yaitu sumber daya alam, modal, dan tenaga kerja. Menurutnya tenaga kerja adalah layanan pribadi pengusaha dan asistennya yang merupakan satu satunya faktor produksi yang beroperasi dalam lingkungan teknik, sumber daya alam, peralatan modal, dan permintaan efektif yang diberikan. Kondisi ini menjelaskan pentingannya mengambil tenaga kerja sebagai unit fisik tunggal yang diperlukan dalam sistem ekonomi, terlepas dari unit uang dan waktu.

Qardhawi menjelaskan setidaknya terdapat dua unsur yang paling utama pada faktor produksi yaitu sumber daya alam dan tenaga kerja. Sumber daya alam yang dimaksud disini adalah segala kekayaan alam yang diciptakan oleh Allah agar bisa dimanfaatkan oleh manusia sebagai bekal yang dibutuhkan. Sedangkan tenaga kerja adalah usaha dalam memberikan jasa untuk membantu berjalannya proses produksi.

Hal ini menjelaskan bahwa faktor produksi bukan hanya dilihat dari sumber daya alam, sumber daya manusia dan modalnya saja, tetapi bagamana agar proses produksi yang dilakukan sesuai dengan aturan serta dilihat juga dari segi nilai etika dan akhlaknya agar dapat meningatkan produktivitas kerja.

\section{Analisis Pemikiran John Maynard Keynes Tentang Produksi}

Keynes menyatakan bahwa kegiatan produksi dan pemilikan faktor-faktor produksi masih dapat dipercayakan kepada swasta, tetapi Pemerintah wajib melakukan kebijakan-kebijakan untuk mempengaruhi perekonomian. Misalnya, dalam masa depresi pemerintah harus bersedia melakukan kegiatan-kegiatan yang langsung dapat menyerap tenaga kerja yang tidak dapat bekerja pada swasta, walaupun hal ini dapat menyebabkan defisit dalam anggaran belanja negara. Dalam hal ini Keynes tidak percaya pada sistem liberalisme yang mengoreksi diri sendiri, untuk kembali pada posisi full employment secara otomatis. Full employment hanya bisa dicapai dengan tindakan-tindakan terencana, bukan datang dengan sendirinya.

Keynes menyatakan bahwa semakin banyak tenaga kerja yang dikombinasikan dengan modal yang tetap, maka akan meningkatkan produksi, berarti bahwa jika tenaga kerja semakin banyak digunakan maka setiap pekerja akan disertai dengan modal yang semakin banyak. Jadi, tambahan output yang diperoleh dari tambahan "satu tenaga kerja lagi" menurun sejalan dengan tambahan tenaga kerjanya. Dengan kata lain dapat dinyatakan bahwa marginal physical product (MPP) menurun sejalan dengan penambahan tenaga kerja.

Hal ini berarti bahwa perusahaan hanya menggunakan satu faktor variabel, yaitu tenaga kerja. Dengan demikian jika ada tambahan satu unit tenaga kerja, maka biaya akan naik sebesar harga per unit jasa tenaga kerja tersebut yang dinamakan tingkat upah nominal.

Setiap individu diasumsikan memperoleh utility dari pendapatan hasil produksi dan waktu senggang. Keynes menjelaskan bahwa pada upah riil, pekerja harus siap bekerja dengan waktu yang ada, tetapi ketika upah riil dinaikkan, maka pekerja justru mengurangi waktu kerjanya. Hal ini 
menunjukkan bahwa pekerja memperhitungkan waktu senggang (leisure) untuk kegiatan-kegiatan seperti istirahat, rekreasi, dan sebagainya.

Tujuan akhir dari suatu produksi menurut Keynes adalah untuk memuaskan konsumen. Waktu yang sudah berlalu, terkadang mengeluarkan biaya oleh produsen dan pembelian output oleh konsumen akhir. Sementara para pengusaha dan investor harus membentuk espektasi kedepan mengenai kebutuhan konsumen yang akan dibayar ketika produsen siap memproduksi barang setelah melewati waktu yang panjang. Hal ini perlu dilakukan agar waktu yang dihabiskan dapat diimbangi oleh hasil output yang dikeluarkan.

Kemungkinan Kelebihan Produksi. Menurut Keynes kelebihan produksi secara umum bisa terjadi. Kelebihan produksi terjadi disebabkan karena permintaan masyarakat terhadap barangbarang dan jasa tidak cukup kuat. Permintaan yang ada tidak cukup untuk menyerap barang dan jasa yang ditawarkan.

Kemungkinan Kekurangan Produksi. Menurut Keynes, umumnya keputusan rumah-tangga untuk konsumsi cukup stabil. Jumlah konsumsi biasanya berubah (naik) jika pendapatan rumahtangga naik. Sedangkan keputusan perusahaan untuk investasi biasanya sukar diterka. Oleh karenanya, gejolak pengeluaran investasi inilah yang sangat menentukan gejolak GDP dan kesempatan kerja.

Kondisi seperti ini dapat dihentikan jika ada keseimbangan antara permintaaan dan penawaran, serta memungkinan bagi pemerintah untuk andil dalam menggambarkan serta memperkirakan pengeluaran rumah tangga dan banyaknya investasi yang beredar di pasar barang, agar dapat dimanfaatkan untuk informasi tambahan bagi para pelaku bisnis dan investor. Hal ini dilakukan untuk menghindari terjadinya kelebihan atau kekurangan produksi.

\section{Analisis Pemikiran Yusuf Qardhawi Tentang Produksi}

Ekonomi Islam sangat menganjurkan dilaksanakannya kegiatan produksi dan mengembangkannya baik dari segi kualitas maupun kuantitas, kekayaan alam dan sumber daya manusia yang memiliki kemampuan untuk memanfaatkan kekayaan alam tersebut tidak boleh disiasiakan begitu saja. Islam menghendaki semua tenaga dikerahkan untuk meningkatkan produktivitas melalui ketekunan yang diridhai Allah SWT atau ikhsan yang diwajibkan Allah SWT atas segala sesuatu.

Islam menganjurkan umatnya untuk bekerja serta mengikuti sunatullah dan hukum kualitas. Islam menerima dan menyambut segala sesuatu yang kehidupan manusia termasuk segala sesuatu yang memudahkan kegiatan produksi. Penggunaan sarana dan alatalat modern untuk meningkatkan mutu produknya, memberikan harga yang terjangkau oleh konsumen. Jika suatu mesin dapat meningkatkan produksi, menghemat tenaga, mengurangin modal, mengurangi jam kerja dan mendatangkan banyak hasil, pasti agama menerima hal itu, yang terpenting adalah terciptanya kemaslahatan bagi manusia, terhindar dari bahaya, terciptanya efektivitas dan efisiensi dalam produksi, maka penggunaan sarana dan alat-alat modern dibenarkan dalam Islam.

Menurut Qardhawi, unsur terpenting dalam produksi yaitu kerja. Produktifitas timbul dari gabungan antara kerja 
manusia dan kekayaan alam "bumi tempat bekerja, sedangkan manusia adalah pekerja di atasnya”. Dalam Islam bekerja adalah suatu kewajiban bagi mereka yang mampu. Tidak dibenarkan bagi seorang muslim berpangku tangan dengan alasan "mengkhususkan waktu untuk beribadah" atau bertawakal. Islam memberkahi pekerjaan dunia dan menjadikannya bagian dari ibadah dan jihad apabila dikerjakan dengan konsisten terhadap peraturan Allah SWT.

Jika bekerja merupakan unsur terpenting dalam berproduksi, maka unsur yang wajib bagi seorang produsen muslim adalah hanya berproduksi pada batasan yang halal. Seorang mukmin yang beriman selalu memperhatikan batasan-batasan Allah SWT dan menjauhi semua yang dilarang-Nya, menolak melakukan dosa dan menjauhkan diri dari apa yang diharamkan.

Etika terpenting dalam produksi adalah menjaga sumber daya alam. Sumber daya alam adalah nikmat Allah SWT dan manusia wajib mensyukurinya, salah satu cara bersyukur atas nikmat tersebut yaitu dengan menjaga kelestariannya, menjaganya dari polusi, kerusakan atau kehancuran. Allah SWT berfirman dalam QS Al-A'raf/ 7: 85:

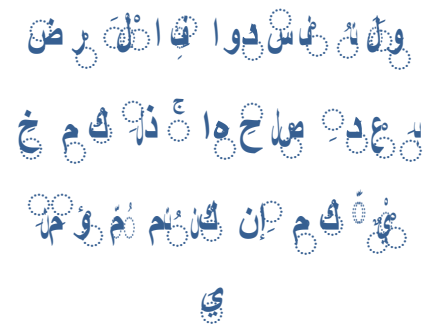

Terjemahnya:

“......dan janganlah kamu membuat kerusakan di muka bumi sesudah Tuhan memperbaikinya. Yang demikian itu lebih baik bagimu jika betul-betul kamu orang-orang yang beriman".
Jika produsen kapitalis mengejar keuntungan tanpa mempedulikan apakah produknya dibutuhkan masyarakat atau tidak, maka produsen muslim memproduksi suatu komoditi berdasarkan kebutuhan masyarakat. Seorang muslim bekerja untuk akhiratnya, sebagaimana ia bekerja untuk dunianya, keridhoan Allah SWT lebih diutamakan daripada memenuhi kebutuhan nafsunya.

\section{Perbandingan Pemikiran John Maynard Keynes dan Yusuf Qardhawi}

Keynes berpendapat bahwa produksi terjadi lewat peranan tiga unsur yang saling berhubungan yaitu sumber daya alam, modal, dan tenaga kerja. Sebagian ahli lain menambahkan unsur disiplin. Menurutnya tenaga kerja adalah layanan pribadi pengusaha dan asistennya yang merupakan satu satunya faktor produksi yang beroperasi dalam lingkungan teknik, sumber daya alam, peralatan modal, dan permintaan efektif yang diberikan. Kondisi ini menjelaskan pentingannya mengambil tenaga kerja sebagai unit fisik tunggal yang diperlukan sistem ekonomi, terlepas dari unit uang dan waktu.

Berbeda halnya jika dibandingkan dengan pemikiran Qardhawi yang menyatakan unsur yang paling utama dalam proses produksi adalah alam dan bekerja. Yang dimaksud alam disini adalah segala kekayaan alam yang diciptakan oleh Allah agar bisa dimanfaatkan oleh manusia sebagai bekal yang dibutuhkan. Sedangkan bekerja adalah segala usaha maksimal yang dilakukan manusia untuk menambah kekayaan, baik dilakukan secara individu maupun kelompok.

Unsur produksi yang dikemukakan oleh kedua tokoh ini sama sama saling berhubungan jika dilihat dari segi konseptual, akan tetapi sangat berbeda dari segi maknanya. Keynes 
menggambarkan tenaga kerja hanya sebagai layanan dan asisten pribadi pengusaha, sedangkan Qardhawi menjelaskan bahwa tenaga kerja merupakan unsur utama dalam produksi, karena manusia merupakan khalifah di muka bumi ini yang dapat memanfaatkan sumber kekayaan alam yang diciptakan Allah dengan cara yang baik. Islam sangat memperhatikan dan menghargai manusia yang bekerja.

Tenaga kerja dalam suatu pekerjaan merupakan salah satu faktor penentu dalam menghasilkan produksi. Menurut Keynes, jika menambah jumlah tenaga kerja maka output yang dihasilkan dari tambahan pekerja tersebut akan mengurangi laba pendapatan, akibat upah nominal. Yang berarti bahwa, jika tambahan tenaga kerja meningkatkan kualitas produksi maka akan meningkatkan permintaan yang betujuan pada memaksimalkan laba.

Qardhawi mejelaskan bahwa pada dasarnya agama lebih memfokuskan tujuan daripada sarana. Islam menganjurkan umatnya untuk berobat tapi tidak menetapkan jenis obat obatan dan cara cara tertentu. Hal ini menunjukkan bahwa Islam tidak ikut campur tangan. Islam memberikan kebebasan kepada setiap manusia untuk berbuat sesuai dengan kreativitas, tingkat keilmuan, situasi dan kondisi.

Kedua pernyataan diatas memiliki perbadaan dari segi tujuan dan sarana. Keynes menyatakan bahwa pendapatan dapat menurun diakibatkan oleh upah nominal. Sedangkan dalam Islam diajarkan upah nominal adalah hak bagi setiap pekerja, bukan hanya melihat dari keuntungan yang didapatkan saja dari sebuah usaha baik individu maupun kelompok, akan tetapi nilai dan perilaku juga harus diperhatikan, untuk meningkatkan nilai keadilan dan produktivitas kerja.

Keynes menggambarkan tujuan invesasi yaitu jika masa mendatang tingkat bunga investasi turun maka seseorang akan membeli obligasi, dengan harapan memperoleh keuntungan kapital (capital gain). Menurutnya pemilik uang wajar mendapatkan bunga sebagai pengganti waktu terhadap uangnya yang disimpan sebagai investasi.

Menurut Qardhawi pembolehan transaksi riba ini dibatah karena berdiri di atas dasar yang sangat lemah. Sebab, tabungan yang dianggap sebagai bayaran atas waktu yang digunakan, tidak sama statusnya pada setiap induvidu maupun kelompok. Sebagian orang yang telah berhasil memenuhi kebutuhannya, tidak terdapat unsur "penantian" dan "penundaan" terhadap pemenuhan kebutuhannya. Lalu atas dasar apakah seseorang mendapatkan riba?

Pernyataan kedua tokoh diatas sangat jelas perbandingannya, karna Keynes menganggap bahwa setiap transaksi harus memperoleh keuntungan dan setiap waktu yang hilang harus dibayar. Hal ini jelas bahwa transaksi tersebut tidak sesuai dengan pemikiran Qardhawi, karna tidak sesuai dengan aturan Islam dan dapat mendatangkan azab Allah. Rasulullah SAW bersabda:

"Jika zina dan riba sudah menyebar di suatu kampung maka sesungguhnya mereka telah menghalalkan azab Allah atas diri mereka sendiri.

Motif spekulasi dalam pandangan keynes didefinisikan sebagai kegiatan peramalan psikologi pasar untuk memperkirakan hasil prospektif aset kedepannya. Hal ini tidak selalu berarti bahwa spekulasi lebih mendominasi perusahaan. Ketika organisasi pasar investasi meningkat, risiko dominasi 
spekulasi juga meningkat. Berbeda dengan pandangan Qardhawi yang menjelaskan bahwa motif spekulasi merupakan tindakan yang dilarang oleh Islam karna merupakan aktivitas gharar yang tingkat ketidak

pastiannya sangat tinggi yang dapat merugikan satu pihak dan bisa menimbulkan tindakan zalim. ${ }^{41}$ Allah berfirman dalam QS. Al-Hud/ 11: 18: Terjemahnya:

"Ingatlah, kutukan Allah (ditimpakan) atas orang-orang yang zalim.

\section{Persamaan Pemikiran John Maynard Keynes dan Yusuf Qardhawi}

Keynes menyatakan bahwa terdapat empat motif kelompok atau perusahaan menahan diri dari pengeluaran dari pendapatan hasil produksi, yaitu yang pertama motif perusahaan ialah untuk mengamankan sumber daya dalam melakukan investasi modal lebih lanjut tanpa menimbulkan hutang atau meningkatkan modal lebih lanjut pada pasar, kemudian motif likuiditas ialah untuk mengamankan dana dalam memenuhi keadaan darurat, kesulitan dan depresi, selanjutnya motif perbaikan ialah untuk mengamankan pendapatan yang meningkat secara bertahap, yang secara kebetulan akan melindungi manajemen dari kritik, sebab peningkatan pendapatan karena akumulasi jarang dibedakan dari peningkatan pendapatan karena efisiensi dan yang terakhir motif kehati-hatian ialah untuk menjaga kestabilan keuangan dengan membuat ketentuan keuangan yang melebihi biaya pengguna dan tambahan, sehingga dapat melepaskan utang dan menghapus biaya aset kedepannya.

Secara umum pendapat Keynes tentang motif pengeluaran baik secara individu maupun kelompok, lebih fokus pada tujuan untuk menjaga aset, walaupun penggunaannya masih jauh dari aturan syariat. Akan tetapi menjaga aset dengan motif perbaikan dan kehati hatian juga merupakan hal penting dalam ajaran Islam.

Nabi SAW berkata jika seseorang menjual suatu aset, maka hasil penjualannya jangan digunakan untuk memenuhi kebutuhan hidup sehari hari, namun hendaklah digunakan untuk membeli aset dari jenis yang sama agar berkah uang itu tetap terjaga Pernyataan Keynes menunjukkan bahwa setiap individu maupun kelompok pasti mempunyai motif atau tujuan dalam memanfaatkan pendapatan dari hasil produksi. Kondisi ini didukung oleh pendapat Qardhawi yang mengatakan bahwa terdapat dua tujuan utama dari produksi yaitu target swasembada individu, Islam menargetkan agar umatnya mencapai standar swadaya dengan memenuhi kebutuhan yang cukup dan tidak berlebihan, seperti cukup makan, cukup air, cukup sandang, cukup papan (tempat tinggal), cukup uang berumah tangga, cukup uang untuk menuntut ilmu, pengobatan apabila sakit dan tabungan haji dan umrah. Kemudian selanjutnya target Swasembada Masyarakat/ Kelompok ialah untuk memenuhi kebutuhan swasembada umat, yang berarti bahwa masyarakat harus memiliki kemampuan, pengalaman, serta metode untuk memenuhi segala kebutuhannya, baik material ataupun spiritual.

Hal ini menunjukkan bahwa pemikiran Keynes dan Qardhawi memiliki tujuan yang sama dalam produksi yaitu bagaimana cara memenuhi dan mencukupi kebutuhan masyarakat dengan baik dan terararah yaitu dengan metode investasi maupun peningkatan kemampuan dalam pengalaman kerja. 
Menurut Keynes penurunan pendapatan hasil produksi disebabkan karena penurunan tingkat pekerjaan, jika terlalu jauh dapat menyebabkan konsumsi melebihi pendapatan tidak hanya oleh beberapa individu dan lembaga yang menggunakan cadangan keuangan yang telah mereka akumulasikan di masa yang lebih baik, tetapi juga oleh pemerintah yang akan bertanggung jawab, mau tidak mau akan mengalami defisit anggaran. Jadi, ketika pekerjaan jatuh ke tingkat yang rendah, konsumsi agregat akan menurun dengan jumlah yang lebih kecil dari pendapatan riil.

Sebaiknya permasalahan ini, pemerintah harus ikut andil dalam hal ini yaitu dengan cara mengawasi serta membimbing masayarakat dalam peningkatkan pendapatan, salah satunya dengan membuka lowongan pekerjaan. Dengan bekerja, masyarakat dapat meningkatkan pendapatan yang kemudian diikuti oleh meningkatnya daya beli konsumsi, dengan ini dapat mengatasi defisit anggaran pemerintah.

Kondisi tersebut didukung oleh pendapat Qardhawi yang menjelaskan bahwa Islam menggariskan bahwa membelanjakan harta tidak boleh melampaui batas, yaitu pengeluaran lebih besar dari jumlah pendapatan atau mementingkan kebutuhan banyak orang daripada kebutuhan pribadinya.

Islam mewajibkan umatnya bertindak moderat, mendahulukan yang primer daripada sekunder, mendahulukan sekunder daripada tersier. Boros adalah sikap tercela dan bertambah tercela jika uang yang dibelanjakan adalah milik orang banyak/ masyarakat. Idealnya, pemegang uang umat (pemerintah) bersikap sederhana dalam mengeluarkan uang dan mencatat keluar masuknya uang walupun satu dinar karena uang tersebut milik rakyat.

Negara dalam Islam tidak saja bertanggung jawab atas keamanan luar dan dalam negri saja tetapi ia juga bertugas mengayomi masyarakat miskin serta menjamin kelangsungan hidupnya.

Keynes berpendapat bahwa penurunan hasil produksi disebabkan karena penurunan tingkat pekerjaan, jika terlalu jauh dapat menyebabkan konsumsi melebihi pendapatan tidak hanya oleh individu dan lembaga yang menggunakan cadangan keuangan yang telah mereka akumulasikan di masa yang lebih baik, tetapi juga oleh pemerintah yang akan bertanggung jawab, mau atau tidak mau akan mengalami defisit anggaran. Jadi, ketika pekerjaan jatuh ke tingkat yang rendah, konsumsi agregat akan menurun dengan jumlah yang lebih kecil dari pendapatan riil.

Kondisi tersebut didukung oleh pendapat Qardhawi yang menjelaskan Islam menekankan bahwa membelanjakan harta tidak boleh melampaui batas, yaitu pengeluaran lebih besar dari jumlah pendapatan atau mementingkan kebutuhan banyak orang daripada kebutuhan pribadinya.

Sebaiknya untuk mengatasi permasalahan ini, pemerintah harus ikut andil dalam hal ini yaitu dengan cara mengawasi serta membimbing masayarakat dalam peningkatkan pendapatan, salah satunya dengan membuka lowongan pekerjaan. Dengan bekerja, masyarakat dapat meningkatkan pendapatan yang kemudian diikuti oleh meningkatnya daya beli konsumsi, dengan ini dapat mengatasi defisit anggaran pemerintah.

\section{Prespektif Ekonomi Syari’ah}




\section{Terhadap pemikiran John Maynard Keynes dan Yusuf Qardhawi}

Tujuan dari ekonomi Islam adalah untuk menciptakan mașlahah yang optimum bagi manusia secara keseluruhan. Dengan mașlahah yang optimum ini, maka akan dicapai falāh yang merupakan tujuan akhir dari kegiatan ekonomi sekaligus tujuan hidup manusia. Falāh itư sendiri adalah kemuliaan hidup di dunia dan akhirat yang akan memberikan kebahagiaan hakiki bagi manusia. Dengan memahami alur tujuan kegiatan produksi ini, maka dapat diambil suatu substansi bahwa karakter penting bagi produksi dalam perspektif ekonomi Islam adalah perhatiannya terhadap kemuliaan harkat kemanusiaan, yaitu mengangkat kualitas dan derajat hidup serta kualitas kemuliaan dari manusia. Kemuliaan harkat kemanusiaan harus mendapat perhatian besar dan utama dalam keseluruhan aktifitas produksi. Segala aktivitas yang bertentangan dengan pemuliaan harkat kemanusiaan dapat dikatakan bertentangan dengan ajaran Islam.

Jiwa tatanan dalam ekonomi Islam adalah keseimbangan (tawazun) dan keadilan $(a l$ adl). Hal ini terlihat jelas pada pengakuan atas hak individu dan masyarakat. Sistem ekonomi yang moderat, tidak menyakiti dan mengangkat yang lemah, namun juga mengakui hak dan prestasi individu dan masyarakat. Etika Islam mengajarkan manusia

untuk menjalin kerjasama, tolongmenolong dan menjauhkan rasa iri dengki dan dendam. Selain itu juga mengajarkan berkasih sayang, terutama kepada yang lemah.

Produsen ekonomi konvensional pada dasarnya tidak mengenal istilah halal dan haram. Tujuan ekonomi bagi mereka adalah untuk memenuhi keinginan pribadi dengan mengumpulkan laba dan harta sebanyak-banyaknya tanpa memperhatikan apakah yang dihasilkan memberikan manfaat atau justru menimbulkan bahaya, baik atau buruk, etis dan tidak etis.

Pandangan Islam terhadap teori teori yang dikemukakan oleh Keynes menunjukkan bahwa ia hanya fokus terhadap keuntungan dan pengembangan asetnya saja tanpa memikirkan dampak sosial, nilai serta norma dan etikanya. Keynes juga menyatakan bahwa motif spekulasi didefinisikan sebagai kegiatan peramalan psikologi pasar untuk memperkirakan hasil prospektif aset kedepannya. Hal ini menunjukkan bahwa ia mempertaruhkan aset dan keuntungannya untuk masa depan perusahaan dengan sesuatu yang syubhat (samar). Bagi seorang muslim akan meninggalkan segala sesuatu yang hukumnya meragukan maupun sesuatu yang menjerumuskannya kepada perbuatan yang haram. Rasulullah SAW bersabda:

"Seseorang tidak sampai pada derajat taqwa hingga ia meninggalkan sesuatu yang diragukan dan mengerjakan yang tidak diragukan".

Hadist ini menjelaskan bahwa segala macam perbuatan harus dilakukan dengan proses yang baik dan benar, yaitu dengan meninggalkan segala macam transaksi yang mengandung unsur keraguan, agar kita dapat sampai pada derajat ketaqwaan.

Jika produsen kapitalis mengejar keuntungan tanpa mempedulikan apakah produknya itu dibutuhkan masyarakat atau tidak, maka produsen muslim memproduksi suatu komoditi berdasarkan kebutuhan masyarakat. Seorang muslim 
bekerja untuk akhiratnya, sebagaimana ia bekerja untuk dunianya, keridhoan Allah SWT lebih diutamakan daripada memenuhi kebutuhan nafsunya.

Pandangan ekonomi Islam terhadap pemikiran Qardhawi menyatakan bahwa teori yang dikemukakan lebih di titik beratkan kepada perbedaan antara ekonomi Islam dengan ekonomi hasil teori manusia, yakni terletak pada nilai dan akhlak. Hal ini meliputi urgensi, kedudukan dan dampaknya dalam berbagai bidang ekonomi. Secara garis besar, tujuan yang ditawarkan oleh Keynes dan Qardhawi dalam kegiatan ekonomi adalah sama, yaitu untuk meningkatkan produktifitas. Namun pada umumnya pemaparan keduannya terhadap kegiatan ekonomi terdapat perbedaan yaitu dalam menyikapi proses dan hasil outputnya.

\section{Penutup}

Dari penelitian ini, maka peneliti mengambil kesimpulan bahwa konsep produksi menurut John Maynard Keynes adalah jika tenaga kerja semakin banyak digunakan untuk menghasilkan produksi, maka setiap pekerja akan disertai dengan modal yang semakin banyak. Jadi, tambahan output yang diperoleh dari tambahan "satu tenaga kerja lagi" menurun sejalan dengan tambahan tenaga kerjanya.

Adapun Konsep Produksi Menurut Yusuf Qardhawi adalah respon atas peringatan Allah SWT akan kekayaan alam. Ekonomi Islam sangat menganjurkan dilaksanakannya kegiatan produksi dan mengembangkannya baik dari segi kualitas maupun kuantitas, kekayaan alam dan sumber daya manusia yang memiliki kemampuan untuk memanfaatkan kekayaan alam tersebut tidak boleh disiasiakan begitu saja. Islam menghendaki semua tenaga dikerahkan untuk meningkatkan produktivitas melalui ketekunan yang diridhai Allah SWT atau ikhsan yang diwajibkan Allah SWT atas segala sesuatu.

Kemudian perbandingan pemikiran Keynes dan Qardhawi yaitu menurut Keynes jika tambahan tenaga kerja meningkatkan kualitas produksi, maka akan meningkatkan permintaan yang betujuan pada memaksimalkan laba. Sedangkan Qardhawi mejelaskan bahwa agama lebih memfokuskan tujuan daripada sarana, bukan tujuan memaksimalkan laba melainkan harus memperhatikan tiga hal yaitu, merawat hasil produksi alam, bekerja untuk menghasilkan sesuatu yang baik yaitu dengan tujuan ibadah, dan berpegang pada semua yang dihalalkan Allah dan tidak melampaui batas.

Adapun persamaan pemikiran kedua tokoh ini yaitu, Keynes menyatakan bahwa terdapat motif utama dalam berproduksi bagi individu maupun kelompok. Motif individu untuk menahan pengeluaran, yaitu untuk membuat simpanan, mengantisipasi kebutuhan, menikmati hasil kerja, menikmati rasa kemandirian dan mewariskan kekayaan. Kemudian motif kelompok terdari dari motif perusahaan, likuiditas, perbaikan dan motif kehati-hatian. Kondisi ini sama dengan pemikiran Qardhawi yang mengatakan bahwa terdapat dua tujuan utama dari produksi yaitu untuk memenuhi kebutuhan swasembada individu dan kebutuhan swasembada Masyarakat/Kelompok.

Selanjutnya prespektif ekonomi syari'ah terhadap pemikiran Keynes menunjukkan bahwa ia hanya fokus terhadap keuntungan dan pengembangan asetnya saja tanpa memikirkan dampak sosial, nilai serta norma dan etikanya. 
Sedangkan Pemikiran Qardhawi mununjukkan bahwa teori yang ia kemukakan lebih di titik beratkan pada perbandingan antara ekonomi Islam dengan ekonomi hasil teori manusia, yakni terletak pada nilai dan akhlak. Hal ini meliputi urgensi, kedudukan dan dampaknya dalam berbagai bidang ekonomi.

Secara garis besar, tujuan yang ditawarkan oleh Keynes dan Qardhawi dalam kegiatan ekonomi adalah sama, yaitu untuk meningkatkan produktifitas. Namun pada umumnya pemaparan keduannya terhadap kegiatan ekonomi terdapat perbedaan yaitu dalam menyikapi proses dan hasil outputnya.

\section{Daftar Pustaka}

Ali, Misbahul. Prinsip Dasar Produksi Dalam Ekonomi Islam, Jurnal Lisan Al-Hal, Vol 5, No 1 Juni 2013

Bangun, Wilson. Teori Ekonomi Mikro. Bandung: Refika Aditama, 2014.

Baroto, Teguh. Perencanaan dan Pengendalian Produksi. Jakarta: Ghalia Indonesia, 2002.

Chaudhry, M. Sharif. Sistem Ekonomi Islam, Prinsip Dasar. Jakarta: Kencana Prenada Media Group, 2012.

Cholidiyah Nurul, dan Mulyawisdawati Richa Angkita, Perilaku Produsen Menurut Yusuf Qardhawi dan Karl Marx, Jurnal ekonomi Islam Laa Maisyir, Vol 5 No 2, 2018.

Departemen Agama RI. Alqur'an dan Terjemahnya. Bandung: CV. Darus Sunnah, 2015.

Dudley Dillard, A Monetary Theory of Production: Keynes and the Institutionalists,

Journal of economic issues Vol 14, No 2 june 1980.
Elliyano, Analisis Pengaruh Disparitas Produksi dan Pendapatan Pekerja Sektoral Terhadap Pertumbuhan Ekonomi Kalimantan Timur, Disertasi, Program Studi Ilmu Ekonomi Universitas Airlangga Kalimantan Timur, 2002.

Fahmi, Khan M. Esai Esai

Ekonomi Islam. Jakarta:

Rajawali pers, 2014. Fahmi,

Irham. Manajemen

Produksi dan Operasi.

Bandung: Alfabeta, 2014.

Gaspersz, Vincent. Manajerial:

Ekonomi

Keputusan Bisnis. Jakarta: Gramedia Pustaka Utama, 2001.

Hanani, Nuhfil dan Kardono. Teori Ekonomi Makro: Pendekatan Grafis dan Matematis.

Malang: Fakultas Ekonomi

Universitas Brawijaya, 2004.

Haming, Murdifin. Manajemen produksi Modern, cet.1. Jakarta: Bumi Aksara, 2012.

Hermawati Efi, Analisis Pengaruh

Faktor Produksi Modal, Bahan

Baku, Tenaga Kerja dan Mesin

Terhadap Produksi Glycerine Pada

PT. Flora Sawita Chemindo

Medan, Tesis Program Studi Ilmu

Manajemen Pada Program

Pascasarjana Universitas Sumatra Utara, 2008.

Kadir, Amiruddin. Konsep Produksi Dalam Perspektif Ekonomi Syariah, Jurnal UIN- Alauddin. Vol 1 No 1. 2014.

Karim, Adiwarman. A. "Ekonomi Mikro Islami” edisi keempat. Jakarta: Raja Grafindo, 2007.

Kriyantono, Rachmat. Teknik praktis riset komunikasi. Jakarta: Kencana, 2010.

Keynes, John M. Alfred Marshall, 18421924, Royal Economic Society and Blackwell Publishing are 
collaborating with JSTOR to digitize, preserve and extend access to The Economic Journal Vol. 34, No. 135 September 1924 The General Theory

Of Employment Interest and Money, Hardcourt: Brace and Word, 1936

Narbuko, Chalid dan Achmadi, Abu. Metodologi Penelitian. Jakarta: Bumi Aksara, 2009.

Nasution, Mustafa Edwin, dkk. Pengenalan Eksklusif Ekonomi Islam. Jakarta: Kencana, 2006.

Mawardi. Ekonomi Islam. Pekanbaru: Alaf Riau, 2007.

Moengin, Parwadi. Konfigurasi Antara Sistem Produksi, Strategi bisnis, Lingkungan Kompetitif dan Budaya Organisasi Pada Perusahaan Manufaktur, Jurnal Media Riset Bisnis \& Manajement, Vol 9 No 2, Agustus 2009.

Mosiba, Risna. Sunnah Sebagai Sumber Iptek dan Peradaban:Studi atas pemikiran Yusuf Al-Qardhawi, Jurnal Inspiratif Pendidikan, Vol. 6. No 2, Juli-Desember 2017.

Muhammad. Ekonomi Mikro Dalam Perspektif Islam. Yogyakarta: BPFE Yogyakarta, 2004.

Prasetyo, Bambang dan Jannah, Lina Miftahul. Metode Penelitian Kuantitatif, Teori dan Aplikasi. Jakarta: Raja Grafindo, 2006.

Qardhawi Yusuf. Fatwa Al-Qaradhawi, terj: Abdurrachman Ali Bauzir Cet-Ke-2. Surabaya: Risalah Gusti, 1996. . Halal wa Haram fil Islam, alih bahasa Mu'ammal Hamidi, Surabaya: PT. Bina Ilmu, 1996. Norma dan Etika Ekonomi Islam, alih bahasa Zaenal
Arifin dan Dahlia Husin, cet. I. Jakarta: Gema Insani Press, 1997. . Peran Nilai dan

Moral dalam Perekonomian Islam. Jakarta: Robbani Press. 2001.

$$
\begin{aligned}
& \text { I, alih bahasa Cecep } \\
& \text { Taufikurrahman, Jakarta: Pustaka }
\end{aligned}
$$
Perjalanan Hidupku Al-Kautsar, 2003.

Rothbard Murray N, "Keynes the Man". Misses Institute, West Magnolia, 2010.

Sari, Widya. Produksi, Distribusi, Dan Konsumsi Dalam Islam, Jurnal Islamiconomic,

Vol 5 No 2. 2014.

Skousen, Mark. The Big Three in Economics. New York: M. E. Sharpe, Inc., 2007. Sugiyono. Metode Penelitian Pendidikan: Pendekatan Kuantitatif, Kualitatif dan $R \& D$. cet. ke-11. Bandung: Alfabeta. 2010.

Sukirno, Sadono. Teori Mikro

Ekonomi, Cet. 14. Jakarta:

Rajawali Press, 2002. Talimah, Ishom. Fiqh Yusuf Qardhawi. Jakarta: Pustaka Al-Kautsar, 2001.

Turmudi, Muhammad. Produksi Dalam Perspektif Ekonomi Islam, Jurnal Islamadina, Vol 18, No. 1, Maret 2017.

Tohani Entoh. Filsafat Organisme Alfred North Whitehead Dan Implikasinya Pada Pendidikan, Jurnal Penelitian Pendidikan vol 4 No 2, Desember 2012

Wahyuni, Sri. Teori Konsumsi Dan Produksi Dalam Perspektif Ekonomi Islam. Jurnal Akuntabel, Vol 10 No. 1 Maret 2013. 